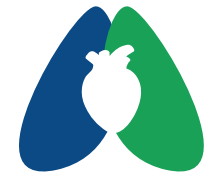

ASSOBRAFIR C I Ê N C I A

\section{Adductor pollicis muscle thickness and the nutritional and functional status in individuals with COPD submitted to pulmonary rehabilitation: a pilot study}

\author{
Espessura do músculo adutor do polegar e o estado nutricional \\ e funcional de indivíduos com DPOC submetidos a reabilitação \\ pulmonar: estudo piloto
}

Luana Redel de Moraes ${ }^{1}$ (D); Ana Amélia Machado Duarte ${ }^{2}$ (1); Gustavo Pereira Reinaldo ${ }^{3}$ (D); Pedro Dal Lago ${ }^{2,3 \#}$ (1); Cintia Pereira de Araujo ${ }^{3 * \#}$ (1)

\begin{abstract}
Background: Loss of muscle mass is an important manifestation in chronic obstructive pulmonary disease (COPD), affecting functional status. In this context, the adductor pollicis muscle thickness (APMT) has been shown to be a useful screening tool for nutritional disorders in hospitalized patients. Aim: To investigate the relationship between APMT and the nutritional and functional status in patients with COPD, as well as to investigate the effects of pulmonary rehabilitation (PR) on APMT. Methods: Patients with COPD were assessed for nutritional status [body mass index, APMT, abdominal and mid-upper arm circumference] and for functional status [limitations in activities of daily living (ADL) and functional capacity assessed by the 6-minute walking test and Glittre-ADL test] and engaged a PR program. Results: Fifteen patients [63.5 \pm 7.4 years and forced expiratory volume in one second $\left(\mathrm{FEV}_{1}\right)$ : $33.4 \pm 15.3 \%$ predicted] were included. APMT showed correlation with $\mathrm{FEV}_{1}(r=0.68 ; p<$ $0.01)$, with the limitation in $A D L(r=0.62 ; p<0.05)$ and with mid-upper arm circumference $(r=0.54 ; p=0.039)$ at baseline. Functional capacity and limitation in ADL improved after PR $(p<0.05)$. APMT was the only nutritional status variable that changed after PR (pre: 11.7 $\pm 2.5 \mathrm{~mm}$ vs. post: $12.5 \pm 1.8 \mathrm{~mm} ; \mathrm{p}<0.05$ ). Conclusion: It is not clear if APMT reflects the nutritional and functional status of patients with COPD. Meanwhile, it may be a responsive tool for muscle mass assessment in this population.
\end{abstract}

Keywords: Chronic Obstructive Pulmonary Disease; Nutritional Status; Anthropometry; Functional Status; Exercise Therapy.

\section{Resumo}

Introdução: A perda de massa muscular é uma manifestação importante na doença pulmonar obstrutiva crônica (DPOC), afetando o estado funcional. Nesse contexto, a espessura do músculo adutor do polegar (APMT) tem se mostrado útil no rastreamento de distúrbios nutricionais em pacientes hospitalizados. Objetivo: Investigar a relação entre a EMAP e o estado nutricional e funcional de pacientes com DPOC e investigar os efeitos da reabilitação pulmonar (RP) na EMAP. Métodos: Pacientes com DPOC foram avaliados quanto ao estado nutricional [índice de massa corporal, EMAP, circunferência abdominal e do braço] e estado funcional [limitações nas atividades de vida diária (AVD) e capacidade funcional avaliada pelo teste de caminhada de 6 minutos e teste de AVD-Glittre] e participaram de um programa de RP. Resultados: Quinze pacientes [63,5 \pm 7,4 anos e volume expiratório forçado no primeiro segundo $\left(\mathrm{VEF}_{1}\right): 33,4 \pm 15,3 \%$ previsto] foram incluídos. A EMAP apresentou correlação com VEF $(r=0,68 ; p<0,01)$, com as limitações nas AVD $(r=0,62 ; p<0,05)$ e com a circunferência do braço $(r=0,54 ; p=0,039)$. Houve melhora na capacidade funcional e nas limitações nas AVD após a RP ( $p<0,05)$. A EMAP foi a única variável nutricional que mudou após a RP (pré: 11,7 $\pm 2,5 \mathrm{~mm}$ vs. pós: $12,5 \pm 1,8 \mathrm{~mm}$; $\mathrm{p}<0,05$ ). Conclusão: Não está claro se a EMAP reflete o estado nutricional e funcional de pacientes com DPOC. Contudo, ela pode ser uma ferramenta responsiva para avaliação da massa muscular nessa população.

Palavras-chave: Doença Pulmonar Obstrutiva Crônica; Estado Nutricional; Antropometria; Estado Funcional; Terapia por Exercício.

*Corresponding author:

Cintia Pereira de Araujo.

Email: cintia_Ipa@yahoo.com.br

\footnotetext{
This an Open Access article published and distributed under a Creative Commons Attribution NonComercial ShareAlike License which permits unrestricted noncommercial use, distribution, and reproduction in any medium provided the original work is properly cited and is not represented as endorsing the use made of the work. Further, any new works must be made available under the same license.
} 


\section{INTRODUCTION}

Skeletal muscle dysfunction and loss of muscle mass are important manifestations in chronic obstructive pulmonary disease (COPD), which impair functional capacity and are related to increased mortality ${ }^{1}$. Even in the absence of weight loss, these patients may present nutritional depletion, characterized by low fatfree mass ${ }^{2,3}$. Nutritional status variables, such as body mass index (BMI) and fat-free mass index (FFMI), are significantly associated with patients' functional status, presenting correlation with exercise capacity, dyspnea and lung function ${ }^{4}$. Therefore, body composition needs to be assessed in this population.

Appropriate measurements of body composition and its surrogate markers in clinical practice usually involve dualenergyX-ray absorptiometry (DEXA), bioelectrical impedance, ultrasound and anthropometry ${ }^{5}$. Anthropometry allows the evaluation of body composition and diagnosis of malnutrition, it supports planning individualized nutritional strategies ${ }^{6}$, as well as it is accessible and inexpensive. The most used anthropometric measures are body weight, height, skinfolds, and circumferences ${ }^{7}$.

In this context, the evaluation of adductor pollicis muscle thickness (APMT), which assess the skeletal muscle compartment ${ }^{8}$, has shown to be related to the reduction of muscle mass and nutritional status in surgical patients ${ }^{9}$, in intensive care ${ }^{10}$ and in patients with cancer ${ }^{11}$. In addition, APMT is associated with handgrip in patients with cancer ${ }^{11}$ and in patients undergoing hemodialysis ${ }^{12}$.

Although evidence suggests APMT as a possible marker of nutritional status, the relationship between APMT and nutritional status in patients with COPD is still unknown. And, up to our knowledge, the relationship of APMT and exercise capacity, limitation in activities of daily living (ADL) or other marker of functional status was not studied in COPD. Thus, the present study aimed to investigate the correlation between APMT and the nutritional and functional status in patients with COPD, and to investigate the effects of pulmonary rehabilitation (PR) on APMT.

\section{METHODS}

\section{Population}

The study included patients with moderate to very severe COPD (stages II to IV of expiratory flow obstruction) ${ }^{13}$, clinically stable during the month prior to the beginning of the study protocol, age $\geq 40$ years and smoking history $\geq 20$ pack-years. Patients presenting any condition that would not enable any of the study assessments or the exercise training, current smokers or presenting associated diseases (cardiovascular, orthopaedical, neurological, cancer) were excluded. None of the subjects had engaged in any exercise training program at least one year before participating in the study.

\section{Study protocol}

Subjects were assessed for lung function at baseline and for nutritional and functional status at baseline and after 24 sessions of PR. The study was approved by the Ethics Committee of the Universidade Federal de Ciências da Saúde de Porto Alegre (CAAE 34047614.9.0000.5345) and all participants signed the informed consent form. This study was registered at Brazilian Clinical Trials Registry (RBR26pms3).

\section{Lung function}

Lung function was assessed with spirometry (before and after bronchodilator). All spirometry were performed as described by the American Thoracic Society (ATS)/European Respiratory Society (ERS) ${ }^{14}$, and the predicted values were calculated ${ }^{15}$. Data regarding postbronchodilator forced expiratory volume in one second $\left(\mathrm{FEV}_{1}\right)$ and forced vital capacity (FVC) were retrieved for analysis.

\section{Nutritional status}

Body weight, height, abdominal circumference (AC), midupper arm circumference (MUAC), triceps skinfold thickness (TSFT) and APMT were assessed. BMI was calculated by dividing weight by the square of the height $\left(\mathrm{kg} / \mathrm{m}^{2}\right)^{7}$ and patients were classified as underweight (BMI $<21 \mathrm{~kg} / \mathrm{m}^{2}$ ), normalweight $\left(21 \leq \mathrm{BMI}<25 \mathrm{~kg} / \mathrm{m}^{2}\right)$, overweight $(25 \leq \mathrm{BMI}$ $<30 \mathrm{~kg} / \mathrm{m}^{2}$ ) or obese $\left(\mathrm{BMI} \geq 30 \mathrm{~kg} / \mathrm{m}^{2}\right)^{16}$.

Body weight was assessed using a $100 \mathrm{~g}$ scale with a maximum load of $180 \mathrm{~kg}$. Height was measured with a stadiometer. The patient was positioned in the upright position, with bare feet, and the posterior surface of the heel, pelvic girdle, scapular girdle, and occipital region were in contact with the equipment. The head was positioned in the horizontal plane of Frankfurt. AC was measured with the patient in the standing position, with the belly relaxed, using an anthropometric tape positioned around the abdomen at navel height ${ }^{7}$. The MUAC measurement was performed on the back of the arm using an anthropometric tape, parallel to the longitudinal axis, at half the distance between the upper lateral edge of the acromion and the olecranon ${ }^{7}$. The TSFT was measured with a plicometer, in the posterior face of the arm, parallel to the longitudinal axis, at the half distance between the upper lateral edge of the acromion and the olecranon ${ }^{7}$. The APMT was measured with a plicometer with continuous pressure of $10 \mathrm{~g} / \mathrm{mm}^{2}$, with the patient seated, the arm flexed at approximately $90^{\circ}$, the forearm and the hand resting on the knee. Patients were instructed to keep their hands relaxed. The adductor muscle was pinched with the plicometer at the apex of an imaginary triangle, formed by the extension of the thumb and index finger. The procedure was performed on the non dominant hand for three times and the mean value was used for analysis ${ }^{8}$.

To classify MUAC and TSFT, the Frisancho's classification ${ }^{17}$ was used, using the 5-15 percentile for 
classification of moderate malnutrition and the lowest 5th percentile for severe malnutrition. Regarding the TSFT, this variable was measured to calculate the muscular circumference of the arm, classifying the 5-15 percentile for moderate malnutrition and the lowest 5 th percentile for severe malnutrition. Patients were classified as increased risk of metabolic complications when $A C \geq 94 \mathrm{~cm}$ for men and $\geq 80 \mathrm{~cm}$ for women and as substantially increased when $A C>102 \mathrm{~cm}$ for men and $>88 \mathrm{~cm}$ for women ${ }^{7}$. The APMT was classified according to the sex as described Lameu et al. ${ }^{8}$ : normal $(>9.5 \mathrm{~mm})$, at nutritional risk $(79.5 \mathrm{~mm})$ and malnutrition ( $<7 \mathrm{~mm}$ ) for men; and normal $(>8 \mathrm{~mm})$, at nutritional risk $(6-8 \mathrm{~mm})$ and malnutrition $(<6 \mathrm{~mm})$ for women.

\section{Functional status}

Functional status was assessed with the six-minute walking test (6MWT), the Glittre-ADL test (TGlittre) and London Chest Activity of Daily Living scale (LCADL).

The 6MWT was performed in accordance to the ATS/ ERS standards ${ }^{18}$ and predicted values for walking distance were calculated ${ }^{19}$.

The TGlittre is a multiple task test validated for patients with COPD ${ }^{20}$, which consists of completing five laps of a circuit of common $A D L$, such as: standing up form a chair, walking, carrying weight, climbing steps, moving objects on a shelf and sitting down. Subjects were instructed to complete the TGlittre as quick as possible. Predicted values for the time to perform the TGlittre were calculated according to Reis et al. ${ }^{21}$. Values over $100 \%$ of the predicted mean that the individual takes more time to complete the test than the expected.

Both 6MWT and TGlittre were performed on separate days, and both tests were performed twice in the same day with a 30-minute interval and the best tests were used for analysis.

The LCADL assesses limitation in ADL due dyspnea. It consists of 15 activities divided into four domains: self-care, domestic, physical and leisure ${ }^{22}$. Higher scores indicate higher functional limitation in daily activities due dyspnea.

\section{Pulmonary rehabilitation program}

Patients participated in a 24-session supervised training program designed according to ATS/ERS ${ }^{23}$. The protocol involved aerobic training and peripheral muscle training three times a week (approximately 90 min each session). The aerobic training was performed in a treadmill with an initial load at $60 \%$ of the mean velocity in the $6 \mathrm{MWT}$, for $30 \mathrm{~min}$. The intensity progression was based on the sensation of dyspnea and fatigue of lower limbs, which should be 4 to 6 on the modified Borg scale.

The lower limb strength training included quadriceps and triceps sural and it was performed with free weights and/or in the extensor chair (two sets of 10 to 15 repetitions). The initial load was established in 30\% of the one-repetition maximum (1RM) according to the predictive equation: $1 \mathrm{RM}=$ load $\times[1+(0.025 \times \text { repetitions })]^{24}$. The four- to twelve-repetition maximum test (4-12RT) was performed to calculate the $1 \mathrm{RM}{ }^{25}$. All patients started the lower limb strength training with three sets of 10 repetitions and, if leg fatigue was $<4$ in the modified Borg scale at the end of the last set, the number of repetitions would be increased to 12 in the next session, and to 15 repetitions after that. When the patient achieved 15 repetitions in each set, the load of the strength training was increased in at least $0.5 \mathrm{~kg}$ every two weeks, according to the leg fatigue (Borg: 4 to 6).

Upper limb training was performed on diagonal axes, with free weights or elastic bands, and each diagonal was performed in two sets, lasting two minutes each. The initial load was established in $0.5 \mathrm{~kg}$ or minimum resistance elastic band, according to the patients' capacity. The load was increased every two weeks, according to arm fatigue (Borg: 4 to 6). Yet, loads above $3 \mathrm{~kg}$ were avoided so as not to harm the shoulder joint.

Also, patients received nutritional counseling and educational guidance regarding self-management of the disease. Nutritional counseling consisted of orientation to eat and what to eat before and after the training sessions, to increase the daily consumption of fresh and minimally processed foods and to reduce the consumption of processed and industrialized foods. No control of food intake was performed.

\section{Statistical analysis}

Data distribution was analyzed using the Shapiro-Wilk test. Correlations were analyzed using the Pearson test, except for the correlations tested with TGlittre and with lung function (FEV 1 and FVC), which were tested with Spearman test. The comparison of APMT between men and women was analyzed with $\mathrm{t}$ test for independent samples. The one-way ANOVA with Bonferroni post hoc was used to compare the APMT between underweight, normal weight, overweight and obese individuals. The effects of PR were analyzed with the test for paired samples, except for the analysis of TGlittre and 6MWT, which were done with the Wilcoxon test. Significance was set at $p<0.05$. All analysis were performed with the software SPSS 22.0 (IBM Corp., Armonk, NY, USA) and the graphs were built with GraphPad Prism 6 (Graph Pad Software Inc., La Jolla, CA, USA).

\section{RESULTS}

The sample consisted of 15 patients ( 5 men), $63.5 \pm 7.4$ years-old, smoking history of $58.0 \pm 34.7$ pack-years; FEV $_{1} /$ FVC ratio: $0.47 \pm 0.11$ and $\mathrm{FEV}_{1}: 33.4 \pm 15.3 \%$ of predicted. According to the BMI classification, four patients were underweight, three had normal weight, four were overweight and four were obese. Only MUAC identified that 
patients presented moderate to severe malnutrition before and after PR (Table 1). Baseline APMT was not statistically different between women and men (11.1 \pm 2.23 vs. $13 \pm 2.64$, respectively; $p=0.159)$. No statistical difference $(p=0.134)$ was found in APMT between underweight (9.52 $\pm 1.41 \mathrm{~mm})$, normal weight $(12 \pm 2.08 \mathrm{~mm})$, overweight $(13.5 \pm 1.04 \mathrm{~mm})$ and obese $(11.9 \pm 3.38 \mathrm{~mm})$ individuals (Figure 1).

At baseline, APMT showed correlation with MUAC $(r=0.54 ; p=0.039)$ and tended to correlate with $A C(r=0.51$; $\mathrm{p}=0.05)$, but APMT did not correlate with neither BMI nor TSFT (Table 2). Furthermore, APMT was the only nutritional variable that correlated with lung function (Figure 2).

Regarding functional status, APMT only correlated with the LCADL score, while both AC and MUAC correlated with TGlittre (Table 2). In addition, APMT was the only nutritional status variable that changed after PR. At the same time, there was an improvement in all functional status variables, except for the physical domain of the LCADL (Table 1).

\section{DISCUSSION}

As expected, functional status improved after PR. APMT was the only nutritional status variable that improved after PR, while no changes in BMI, AC, MUAC and TSFT were observed. Correlations between baseline APMT and
MUAC, lung function, and LCADL were found. At the same time, TGlittre correlated with both AC and MUAC. Still, no differences in APMT between underweight, normal weight, overweight and obese patients were found.

It is well established that PR is an effective therapy in improving exercise capacity, muscle strength, symptoms and health status for patients with COPD ${ }^{23}$. However, improving body composition abnormalities is still

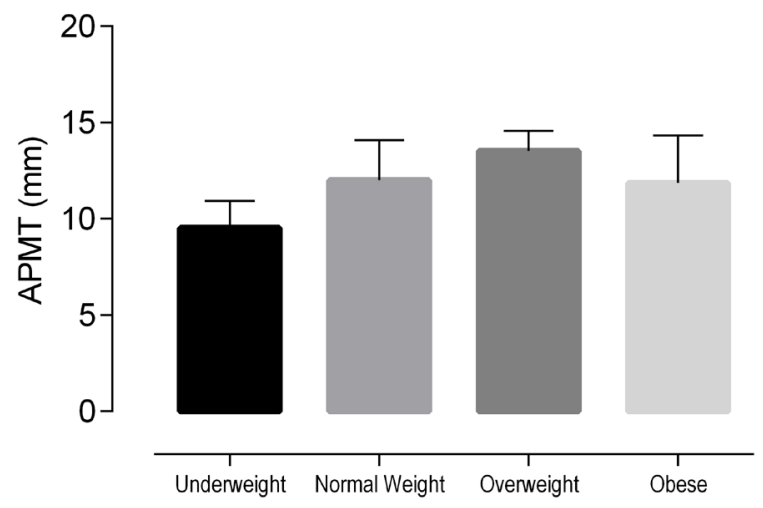

Figure 1. Comparison of adductor pollicis muscle thickness (APMT) between underweight, normal weight, overweight and obese patients with COPD. $p>0.05$ for all.

Table 1. Variables studied before and after pulmonary rehabilitation protocol in individuals with COPD $(n=15)$.

\begin{tabular}{|c|c|c|c|c|c|}
\hline & \multicolumn{2}{|c|}{ Baseline } & \multicolumn{2}{|c|}{ After Pulmonary Rehabilitation } & \multirow{2}{*}{$\mathrm{p}$} \\
\hline & Mean/Median & $\mathrm{SD} / \mathrm{IQR}$ & Mean/Median & $\mathrm{SD} / \mathrm{IQR}$ & \\
\hline Weight, kg & 64.7 & 15.4 & 65.7 & 14.9 & 0.126 \\
\hline $\mathrm{BMI}, \mathrm{kg} / \mathrm{m}^{2}$ & 25.4 & 6.39 & 25.8 & 6.13 & 0.206 \\
\hline APTM, mm & 11.7 & 2.46 & 12.5 & 1.86 & 0.039 \\
\hline $\mathrm{MUAC}, \mathrm{cm}$ & 25 & 6.79 & 25.3 & 6.28 & 0.555 \\
\hline TSFT, cm & 19.6 & 5.59 & 19.9 & 5.93 & 0.594 \\
\hline $\mathrm{AC}, \mathrm{cm}$ & 79.3 & 18.1 & 79.7 & 18.2 & 0.703 \\
\hline 6MWT, m & $414^{*}$ & $309-423$ & $420 *$ & $363-511$ & 0.011 \\
\hline 6MWT, \%pred & $71^{*}$ & $60-79$ & $78^{*}$ & $67-87$ & 0.016 \\
\hline TGlittre, min & $4.9^{*}$ & $3.6-7.05$ & $4.1^{*}$ & $3.3-4.8$ & 0.005 \\
\hline TGlittre, \%pred & $122^{*}$ & $90.8-172$ & $99.2^{*}$ & $86-117$ & 0.005 \\
\hline LCADL, score & 34.3 & 12.9 & 29.7 & 9.88 & 0.02 \\
\hline Self-care & 9.6 & 3.22 & 7.27 & 1.79 & 0.027 \\
\hline Domestic & 13.33 & 9.39 & 13.4 & 8.61 & 0.949 \\
\hline Physical & 5.2 & 1.2 & 4.46 & 1.18 & 0.028 \\
\hline Leisure & 6.2 & 1.85 & 4.53 & 1.35 & 0.001 \\
\hline
\end{tabular}

Data shown as mean and standard deviation (SD) or * median and 25\%-75\% interquartile range (IQR). APMT: adductor pollicis muscle thickness; BMI: body mass index; AC: abdominal circumference; MUAC: mid-upper arm circumference; TSFT: triceps skinfold thickness; 6MWT: six-minute walking test; TGlittre: Glittre-ADL test; \%pred: percentage of the predicted value; LCADL: London Chest Activity of Daily Living scale total score; Self-care: LCADL selfcare activities domain; Domestic: LCADL domestic activities domain; Physical: LCADL physical activities domain; Leisure: LCADL leisure activities domain. 
Table 2. Correlations between the baseline variables $(n=15)$.

\begin{tabular}{|c|c|c|c|c|c|c|c|c|}
\hline & APMT & BMI & $A C$ & MUAC & TSFT & $6 \mathrm{MWT}$ & TGlittre ${ }^{\rho}$ & LCADL \\
\hline APMT & 1 & & & & & & & \\
\hline BMI & 0.20 & 1 & & & & & & \\
\hline$A C$ & 0.51 & $0.78^{* *}$ & 1 & & & & & \\
\hline MUAC & $0.54^{*}$ & $0.78^{* *}$ & $0.97 * \star$ & 1 & & & & \\
\hline TSFT & 0.34 & $0.74^{\star *}$ & $0.90 * *$ & $0.90 * *$ & 1 & & & \\
\hline 6MWT & 0.11 & 0.17 & 0.32 & 0.27 & 0.31 & 1 & & \\
\hline TGlittre ${ }^{\rho}$ & 0.29 & 0.43 & $0.62^{*}$ & $0.67 * *$ & 0.40 & $0.63 *$ & 1 & \\
\hline LCADL & 0.57 * & 0.34 & 0.12 & 0.03 & 0.23 & 0.28 & 0.20 & 1 \\
\hline
\end{tabular}

APMT: adductor pollicis muscle thickness; BMI: body mass index; AC: abdominal circumference; MUAC: mid-upper arm circumference; TSFT: triceps skinfold thickness; 6MWT: distance walked in the six-minute walking test; TGlittre: time spent in the Glittre-ADL test; LCADL: London Chest Activity of Daily Living scale. ${ }^{p}$ Spearman's rank correlation coefficient. * $p<0.05 ; * * p<0.01$.

A

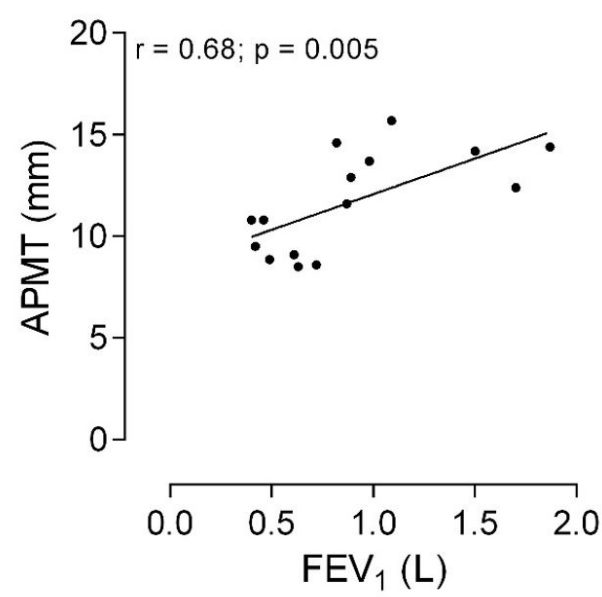

B

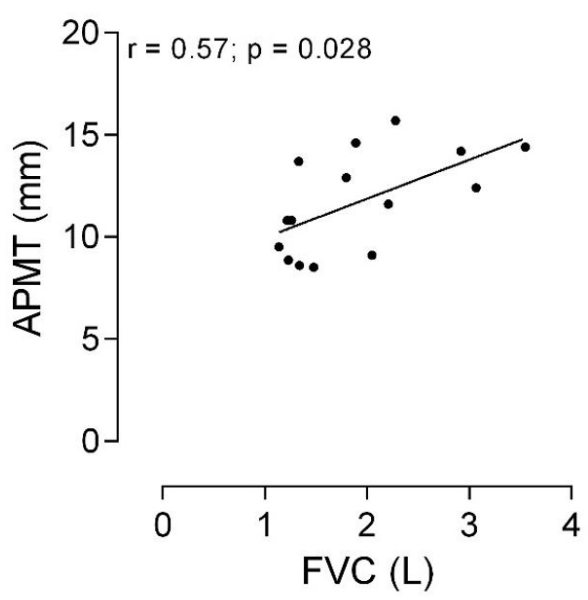

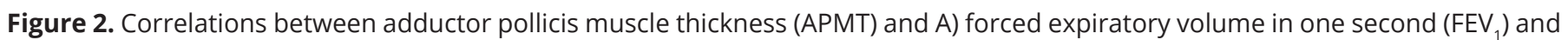
B) forced vital capacity (FVC).

challenging. It has been shown that exercise programs not including peripheral strength training does not change whole body fat-free mass ${ }^{26}$. Meanwhile, a leg strength training program was related to a modest local increase in leg muscle mass ${ }^{27}$ and the addition of strength training to aerobic training was related to greater increases in muscle strength and mass (thigh muscle crosssectional area), but did not provide additional improvement in exercise capacity or quality of life ${ }^{28}$.

Although APMT increased after PR, no other nutritional variables have changed in the current study. It is important to point out that the strength of the adductor pollicis muscle is preserved in patients with stable COPD, whereas quadriceps strength is substantially reduced ${ }^{29}$. A previous study demonstrated that during high-intensity leg exercise, the adductor pollicis muscle (a non-exercising muscle) was exposed to the same acidotic milieu as the diaphragm, but its twitch force was unchanged after the exercise protocol ${ }^{30}$. The APMT is the only muscle that allows direct evaluation and measurement of its thickness, since it is located between two bones and has a defined anatomical location ${ }^{8}$. In addition, APMT is easily accessible and is minimally affected by adherent subcutaneous adipose tissue ${ }^{31}$. In this sense, we can hypothesize that there was a shift from fat-mass towards fat-free mass, causing MUAC and BMI to remain unchanged in the current sample of patients. Thus, APMT may have been able to detect this gain of muscle mass, suggesting that APMT may be a responsive tool to assess nutritional changes after PR. On the other hand, the current sample should hold the free weighs or the elastic bands to perform the upper limbs training and this isometric contraction could have increased the APMT. Further studies including body composition assessment, such as DEXA or bioelectrical impedance are needed to clarify this finding. 
Previous reports showed that weight loss and underweight status are most prevalent in advanced disease and in the emphysematous phenotype ${ }^{32}$, while obesity and fat abundance are more prevalent in mild COPD ${ }^{33}$. Patients with severe COPD who are overweight or obese have greater fat-free mass compared to those with normal weight or underweight with the same degree of airflow obstruction ${ }^{34}$, which could be the reason for the tendency of a correlation between APMT and AC found in the current study. Meanwhile, $20-30 \%$ of normal weight individuals with COPD are characterized by a shift in body composition toward muscle wasting and relative abundance of fat mass, independent of spirometric severity ${ }^{35}$. This shift in body composition might explain the lack of correlation between APMT and TSFT, once APTM is little affected by subcutaneous adipose tissue ${ }^{31}$, as well as it might explain the correlation found between APMT and MUAC, since the MUAC is influenced by both muscle mass and adipose tissue. However, we did not find statistical differences in APMT between underweight, normal weight, overweight and obese patients with COPD. Still, we must acknowledge that a type two error may have occurred, since current the sample size is small.

Interestingly, we found a positive correlation between APMT and lung function, as well as a negative correlation between the limitation in ADL assessed by LCADL score. Although it seems unlikely that the airflow obstruction per se affects peripheral skeletal muscle structure or function ${ }^{36}$, its decline might be related to the decline in exercise capacity in these patients ${ }^{37}$, which might lead to disuse that contributes significantly to the alterations in skeletal muscle structure and function in COPD. Thus, APMT might be an option for assessing lean mass, once bioelectrical impedance seems to underestimate fat-free mass in extremely wasted patients (due to shrinkage of intracellular mass) ${ }^{38}$ and to overestimate fat-free mass in unstable patients with extracellular water expansion ${ }^{23}$. However, APMT was only moderately correlated to lean mass in adults ${ }^{31}$. Still, further studies for validation of the APMT as a tool for assessing lean mass in patients with COPD are needed.

While the APMT presented correlation with the disease severity (lung function) and the limitations in ADL, it did not present correlation with the functional capacity (TGlittre and 6MWT). On the other hand, AC and MUAC positively correlated with TGlittre. This means that the higher the $A C$ and the MUAC, the longer patient takes to perform the test, in other words, the more functional limited the patient is. It suggests that patients with more fat mass present limitation in ADL, especially in activities besides walking. It has been reported that obese patients present lower tolerance in weight-bearing activities (i.e. walking) ${ }^{39}$. Reis et al. ${ }^{21}$ showed that BMI is an important predictor for the performance of TGlittre, especially in individuals with $\mathrm{BMI}<35 \mathrm{~kg} / \mathrm{m}^{2}$. Furthermore, Monteiro et al. ${ }^{40}$ reported that obese subjects (BMI: $44 \pm 6 \mathrm{~kg} / \mathrm{m}^{2}$ ) performed the TGlittre in approximately $3.1 \mathrm{~min}$, while individuals submitted to bariatric surgery (BMI: $28 \pm 4 \mathrm{~kg} / \mathrm{m}^{2}$ ) performed the test in approximately $2.18 \mathrm{~min}$ and control individuals (BMI: $27 \pm 6 \mathrm{~kg} / \mathrm{m}^{2}$ ) in $2.03 \mathrm{~min}$.

We acknowledge that this study has limitations. This was a single-center study with a small sample size. Information regarding body composition, such as DEXA or bioelectrical impedance, would also have enriched the information regarding the applicability of APMT in COPD, as well as the assessment of muscle strength. Nevertheless, up to our knowledge, this is the first study investigating the relationship between APMT and the nutritional and functional status in patients with COPD, as well as its response to PR. Further studies on the relationship between APMT and body composition assessed with DEXA or bioelectrical impedance, as well as with functional status should be performed for better understanding the clinical relevance of the APMT in patients with COPD.

\section{CONCLUSION}

It is still not clear if APMT reflects the nutritional and functional status of patients with COPD. Meanwhile, it may be a responsive tool for muscle mass assessment in this population, since APMT increased after PR. Further studies with larger samples are necessary to better understand the relationship of APMT and nutritional and functional status in COPD.

\section{FUNDING}

Nothing to declare.

\section{CONFLICT OF INTEREST}

Nothing to declare.

\section{REFERENCES}

1. Choudhury G, Rabinovich R, MacNee W. Comorbidities and systemic effects of chronic obstructive pulmonary disease. Clin Chest Med. 2014;35(1):10130. http://dx.doi. org/10.1016/j.ccm.2013.10.007. PMid:24507840.

2. Vermeeren MAP, Creutzberg EC, Schols AMWJ, Postma DS, Pieters WR, Roldaan AC, et al. Prevalence of nutritional depletion in a large outpatient population of patients with COPD. Respir Med. 2006;100(8):134955. http://dx.doi. org/10.1016/j.rmed.2005.11.023. PMid:16412624.

3. Humphreys K, Cross G, Frith P, Cafarella P. Nutritional status and dietary intake of outpatients with chronic obstructive pulmonary disease. Nutr Diet. 2008;65(2):16874. http:// dx.doi.org/10.1111/j.17470080.2008.00235.x.

4. Ischaki E, Papatheodorou G, Gaki E, Papa I, Koulouris N, Loukides S. Body mass and fat-free mass indices in COPD: relation with variables expressing disease severity. Chest. 2007;132(1):1649. http://dx.doi.org/10.1378/chest.062789. PMid:17505043.

5. Schols AM, Ferreira IM, Franssen FM, Gosker HR, Janssens W, Muscaritoli M, et al. Nutritional assessment 
and therapy in COPD: a European Respiratory Society statement. Eur Respir J. 2014;44(6):150420. http://dx.doi. org/10.1183/09031936.00070914. PMid:25234804.

6. Cederholm T, Bosaeus I, Barazzoni R, Bauer J, van Gossum A, Klek S, et al. Diagnostic criteria for malnutrition: an ESPEN Consensus Statement. Clin Nutr. 2015;34(3):33540. http:// dx.doi.org/10.1016/j.clnu.2015.03.001. PMid:25799486.

7. WHO: World Health Organization. Physical status: the use and interpretation of anthropometry. Report of a WHO Expert Committee. World Health Organ Tech Rep Ser. 1995;854:1452. PMid:8594834.

8. Lameu EB, Gerude MF, Campos AC, Luiz RR. The thickness of the adductor pollicis muscle reflects the muscle compartment and may be used as a new anthropometric parameter for nutritional assessment. Curr Opin Clin Nutr Metab Care. 2004;7(3):293301. http://dx.doi.org/10.1097/0 007519720040500000009. PMid:15075921.

9. Gonzalez MC, Duarte RRP, Orlandi SP, Bielemann RM, BarbosaSilva TG. Adductor pollicis muscle: a study about its use as a nutritional parameter in surgical patients. Clin Nutr. 2015;34(5):10259. http://dx.doi.org/10.1016/j. clnu.2014.11.006. PMid:25467064.

10. Ghorabi S, Ardehali H, Amiri Z, Shariatpanahi ZV. Association of the adductor pollicis muscle thickness with clinical outcomes in intensive care unit patients. Nutr Clin Pract. 2016;31(4):5236. http://dx.doi. org/10.1177/0884533615621547. PMid:26869610.

11. Valente KP, Almeida BL, Lazzarini TR, Souza VF, Ribeiro T SC, Moraes RAG, et al. Association of Adductor Pollicis Muscle Thickness and Handgrip Strength with nutritional status in cancer patients. PLoS One. 2019;14(8):e0220334. http:// dx.doi.org/10.1371/journal.pone.0220334.

12. Pereira RA, Caetano AL, Cuppari L, Kamimura MA. Adductor pollicis muscle thickness as a predictor of handgrip strength in hemodialysis patients.J Bras Nefrol. 2013;35(3):17784. http:// dx.doi.org/10.5935/01012800.20130029. PMid:24100736.

13. GOLD. Global strategy for the diagnosis, management, and prevention of COPD. COPD Report. 2020;16(2)

14. Miller MR, Hankinson J, Brusasco V, Burgos F, Casaburi R, Coates A, et al. Standardisation of spirometry. Eur Respir J. 2005;26(2):31938. http://dx.doi.org/10.1183/09031936.05. 00034805. PMid: 16055882.

15. Pereira CA, Sato T, Rodrigues SC. New reference values for forced spirometry in white adults in Brazil. J Bras Pneumol. 2007;33(4):397406. http://dx.doi.org/10.1590/ S180637132007000400008. PMid:17982531.

16. Schols AMWJ, Broekhuizen R, WelingScheepers CA, Wouters EF. Body composition and mortality in chronic obstructive pulmonary disease. Am J Clin Nutr. 2005;82(1):539. http:// dx.doi.org/10.1093/ajcn/82.1.53. PMid:16002800.

17. Frisancho A. Anthropometric standards for the assessment of growth and nutritional status. anthropometric standards for the assessment of growth and nutritional Status. Ann Arbor: University of Michigan Press; 1990. http://dx.doi. org/10.3998/mpub.12198.

18. Holland AE, Spruit MA, Troosters T, Puhan MA, Pepin V, Saey $D$, et al. An official European Respiratory Society/American Thoracic Society technical standard: field walking tests in chronic respiratory disease. Eur Respir J. 2014;44(6):142846.

19. Britto RR, Probst VS, Andrade AFD, Samora GAR, Hernandes NA, Marinho PEM, et al. Reference equations for the sixminute walk distance based on a Brazilian multicenter study. Braz J Phys Ther. 2013;17(6):55663. http://dx.doi. org/10.1590/S141335552012005000122. PMid:24271092.
20. Skumlien S, Hagelund T, Bjortuft O, Ryg MS. A field test of functional status as performance of activities of daily living in COPD patients. Respir Med. 2006;100(2):31623. http:// dx.doi.org/10.1016/j.rmed.2005.04.022. PMid:15941658.

21. Reis CM, Karloh M, Fonseca FR, Biscaro RRM, Mazo GZ, Mayer AF. Functional capacity measurement: reference equations for the Glittre Activities of Daily Living test. J Bras Pneumol. 2018;44(5):3707. http://dx.doi.org/10.1590/ s180637562017000000118. PMid:30020345.

22. Garrod R, Paul EA, Wedzicha JA. An evaluation of the reliability and sensitivity of the London Chest Activity of Daily Living Scale (LCADL). Respir Med. 2002;96(9):72530. http:// dx.doi.org/10.1053/rmed.2002.1338. PMid:12243319.

23. Spruit MA, Singh SJ, Garvey C, Zuwallack R, Nici L, Rochester C, et al. An official American Thoracic Society/ European Respiratory Society statement: key concepts and advances in pulmonary rehabilitation. Am J Respir Crit Care Med. 2013;188(8):e1364. http://dx.doi.org/10.1164/ rccm.2013091634ST. PMid:24127811.

24. O'Connor R, Simmons J, O'Shea P. Weight Training Today. St Paul: West Publishing; 1989.

25. Thompson WR, Gordon NF, Pescatello LS. ACSM's guidelines for exercise testing and prescription. Philadelphia: Lippincott Williams \& Wilkins; 2009.

26. Creutzberg EC, Wouters EFM, Mostert R, Pluymers RJ, Schols AMWJ. A role for anabolic steroids in the rehabilitation of patients with COPD? *. Chest. 2003;124(5):173342. http:// dx.doi.org/10.1378/chest.124.5.1733.PMid:14605042.

27. Casaburi R, Bhasin S, Cosentino L, Porszasz J, Somfay A, Lewis $\mathrm{MI}$, et al. Effects of testosterone and resistance training in men with chronic obstructive pulmonary disease. Am J Respir Crit Care Med. 2004;170(8):8708. http://dx.doi. org/10.1164/rccm.2003056170C. PMid:15271690.

28. Bernard $S$, Whittom $F$, Leblanc $P$, Jobin J, Belleau R, Bérubé $C$, et al. Aerobic and strength training in patients with chronic obstructive pulmonary disease. Am J Respir Crit Care Med. 1999;159(3):896901. http://dx.doi.org/10.1164/ ajrccm.159.3.9807034. PMid:10051269.

29. Man WDC, Soliman MG, Nikoletou D, Harris ML, Rafferty GF, Mustfa N, et al. Nonvolitional assessment of skeletal muscle strength in patients with chronic obstructive pulmonary disease. Thorax. 2003;58(8):6659. http://dx.doi.org/10.1136/ thorax.58.8.665. PMid:12885979.

30. Mador MJ, Dahuja M. Mechanisms for diaphragmatic fatigue following highintensity leg exercise. Am J Respir Crit Care Med. 1996;154(5):14849. http://dx.doi.org/10.1164/ ajrccm.154.5.8912769. PMid:8912769.

31. Bielemann RM, Horta BL, Orlandi SP, BarbosaSilva TG, Gonzalez MC, Assunção MC, et al. Is adductor pollicis muscle thickness a good predictor of lean mass in adults? Clin Nutr. 2016;35(5):10737. http://dx.doi.org/10.1016/j. clnu.2015.07.022. PMid:26286900.

32. Engelen MP, Schols AM, Lamers RJ, Wouters EF. Different patterns of chronic tissue wasting among patients with chronic obstructive pulmonary disease. Clin Nutr. 1999;18(5):27580. http://dx.doi.org/10.1016/ S02615614(98)800241. PMid:10601534.

33. Steuten LMG, Creutzberg EC, Vrijhoef HJM, Wouters EF. COPD as a multicomponent disease: inventory of dyspnoea, underweight, obesity and fat free mass depletion in primary care. Prim Care Respir J. 2006;15(2):8491. http://dx.doi. org/10.1016/j.pcrj.2005.09.001. PMid:16701766.

34. Sabino PG, Silva BM, Brunetto AF. Nutritional status is related to fat-free mass, exercise capacity and inspiratory strength in severe chronic obstructive pulmonary disease patients. 
Clinics. 2010;65(6):599605. http://dx.doi.org/10.1590/ S180759322010000600007. PMid:20613936.

35. Schols AM, Mostert R, Soeters PB, Wouters EF. Body composition and exercise performance in patients with chronic obstructive pulmonary disease. Thorax. 1991;46(10):6959. http://dx.doi.org/10.1136/thx.46.10.695. PMid:1750015.

36. Wüst RCl, Degens H. Factors contributing to muscle wasting and dysfunction in COPD patients. Int J Chron Obstruct Pulmon Dis. 2007;2(3):289300. PMid:18229567.

37. Oga T, Nishimura K, Tsukino M, Sato S, Hajiro T, Mishima M. Exercise capacity deterioration in patients with COPD: longitudinal evaluation over 5 years. Chest. 2005; 128(1):629. http://dx.doi.org/10.1378/chest.128.1.62.PMid:16002917.
38. Creutzberg EC, Schols AMWJ, WelingScheepers CAPM, Buurman WA, Wouters EFM. Characterization of nonresponse to high caloric oral nutritional therapy in depleted patients with chronic obstructive pulmonary disease. Am J Respir Crit Care Med. 2000;161(3):74552. http://dx.doi.org/10.1164/ ajrccm.161.3.9808075. PMid:10712317.

39. Maatman RC, Spruit MA, van Melick PP, Peeters JPI, Rutten EPA, Vanfleteren LEGW, et al. Effects of obesity on weightbearing versus weightsupported exercise testing in patients with COPD. Respirology. 2016;21(3):4838. http:// dx.doi.org/10.1111/resp.12700. PMid:26647921.

40. Monteiro F, Ponce DAN, Silva H, Carrilho AF, Pitta F. Validity and reproducibility of the Glittre ADLTest in obese and postbariatric surgery patients. Obes Surg. 2017;27(1):1104. http://dx.doi.org/10.1007/s1169501622447. PMid:27317008. 